\title{
E.H. Kocblx
}

\section{ФЕВРАЛЬСКАЯ РЕВОЛЮЦИЯ 1917 Г. И ПЕРИОДИЧЕСКАЯ ПЕЧАТЬ СИБИРИ}

\begin{abstract}
Исследуются партийно-классовая дифференциация периодической печати Зауралья в первые месяцы революционных событий 1917 г., быстрый количественный и частично качественный рост в это время, конкретное состояние и развитие общественного и индивидуального сознания населения Сибири. В регионе сложилась принципиально новая политическая ситуация: было свергнуто самодержавие, провозглашены политические свободы и свобода печати, Россия стала самой свободной страной в воюющем мире.

Ключевые слова: газеты; журналы; периодика; идейно-политическая борьба; политические партии и группировки Сибири; агитационно-пропагандистское воздействие печати на население; полиграфическая промышленность региона.
\end{abstract}

Февральская буржуазно-демократическая революция представляла собой громадный взрыв всего российского общества, в результате которого в России сложилась принципиально новая политическая ситуация: было свергнуто самодержавие, провозглашены политические свободы. Россия стала самой свободной страной в воюющем мире. Среди прочих свобод Временным правительством была провозглашена и свобода печати. В законе о печати отмечалось: «Печать и торговля произведениями печати свободны. Применение к ним административных взысканий не допускается» [1. Л. 4]. Хотя военная цензура осталась в неприкосновенности, гражданская, тыловая, цензура упразднялась, несмотря на мировую войну. Ушли в прошлое аресты и штрафы редакторов, белые пятна на месте изъятых материалов на страницах газет и журналов.

Одним из следствий провозглашения свободы печати в России стал быстрый рост сибирских периодических изданий. В феврале 1917 г. здесь выходили 33 газеты, в марте - уже 72, в апреле -81 , в мае -88 , в июне - 94 и т.д. до высшей точки в сентябре 101 название. Рост за март-сентябрь - более чем трёхкратный. Такого всплеска журнальной продукции в Сибири ранее не наблюдалось [2. С. 88, 92-93].

Его отсутствие, на наш взгляд, можно объяснить тем, что, во-первых, журнал - это менее оперативный и менее массовый источник информации и, вовторых, тем, что во время Первой мировой войны и быстрого роста цен издание журнала в провинции стоило значительно дороже, чем газеты.

В ходе Февральской революции началась быстрая классово-партийная дифференциация периодической печати, поскольку Россия в 1917 г. представляла собой страну с антагонистическим классовым обществом. А в таком обществе неизбежны идейнополитическое противоборство, идейно-политическая борьба классов, партий, индивидов, поскольку конкретное состояние общественного бытия исторической эпохи находит своё отражение в общественном сознании. Общественное сознание же, как известно, представляет собой совокупность идей, взглядов, представлений, существующих в обществе. В них отражается социальная действительность. Нас в данном случае должно интересовать политическое сознание, которое выражается как в идеологической форме, так и в психологических образованиях: социальных настроениях, духовной атмосфере, революционном энтузиаз- ме. В формировании политического сознания на личностном уровне важная роль отводилась и отводится политической агитации и пропаганде.

Основные виды и средства политической агитации и пропаганды делятся, как правило, на устные, основанные на непосредственном воздействии на личность путем публичных выступлений и дискуссий, и так называемые средства массовой информации. Поскольку в данных конкретно-исторических условиях отсутствовали такие электронные средства массовой информации, как Интернет, радио, телевидение, средством массовой информации выступала периодическая печать.

При неразвитости дорожной сети в Сибири представители политических партий и течений физически не могли охватить устной агитацией и пропагандой отдаленные деревни и сёла огромного региона. Пропагандистских сил едва хватало, чтобы провести массовые митинги, собеседования, собрания в городах и близлежащих сёлах. Во время и после Февральской революции газеты и журналы Сибири являлись фактическим стержнем всех трёх пропагандистских систем (пролетарско-большевистской, буржуазнокадетской и мелкобуржуазной, точнее её назвать социалистической). Редакции этих изданий направляли свои усилия на сплочение и консолидацию социальных групп, слоев, партий и политических течений, выразителями интересов которых они становились. Они направляли свои усилия также на то, чтобы привлечь союзников из других, главным образом промежуточных слоев и групп населения. Они пытались формировать у населения региона нужные им социальные чувства, убеждения, мировоззрение.

Это было необходимо в то поистине судьбоносное время, поскольку хотя Февральская революция и превратила Россию по политическому строю в одну из передовых стран мира, но не разрешила тех основных экономических, социальных, общеполитических и межнациональных противоречий, которые, переплетаясь в тугой узел, лежали в основе общего кризиса российского общества. Перед страной, как справедливо отметил П.В. Волобуев, стояли задачи необычайной трудности и важности: выхода из войны, борьбы с разрухой и голодом, демократического устройства государства; требовали решения аграрный, рабочий и национальный вопросы [3. С. 23-28].

Ввиду этого вопрос о методах, способах решения данных задач объективно встал как вопрос о выборе 
направления дальнейшего исторического развития России. Вокруг этого и сосредоточилась вся идейнополитическая борьба конкретных людей, социальных групп, слоев и классов.

Кадеты Сибири (в период с марта по октябрь 1917 г. возникли 22 кадетские организации с общим числом 2 500-2 600 членов) шли в фарватере политики кадетов центра. Их периодическая печать пропагандировала те же идеи (отличия имелись лишь по отношению к областничеству). В частности, редакция буржуазно-кадетской «Иркутской жизни» уже 4 марта 1917 г. заявила в передовой статье «Новая власть»: «Вначале во главе революционного правительства встала Государственная дума, которая отказалась подчиниться указу о роспуске и, поддержанная армией, встала на защиту страны против прежней власти». Так начал закрепляться в сознании населения Сибири миф о том, что Февральская буржуазно-демократическая революция в Петрограде с самого начала возглавлялась Временным комитетом Государственной думы во главе с М.В. Родзянко. Таким образом уже тогда начал принижаться общенародный характер второй русской революции, когда в едином стремлении свергнуть царизм слились совершенно разные классовые потоки революции.

Легитимность и преемственность новой государственной власти - буржуазного Временного правительства России - всячески подчеркивались в буржуазно-кадетских изданиях Сибири начала марта 1917 г.: «Сибирская жизнь» (Томск), «Иркутская жизнь», «Сибирские войсковые ведомости» (Омск), «Алтай» (Бийск) и другие газеты, а также буржуазнодемократические журналы старательно перепечатывали из столичных газет «Манифест об отречении Императора Николая II от престола» (от 2 марта), «Манифест об отказе Великого князя Михаила Александровича от восприятия Верховной власти» (от 3 марта), обращение к населению «От Временного правительства». Так, в «Манифесте об отказе Великого князя Михаила Александровича от восприятия Верховной власти», опубликованном в сибирских буржуазно-кадетских газетах 4-5 марта 1917 г., говорилось: «...прошу всех граждан Державы Российской подчиниться Временному правительству, по почину Государственной думы, возникшему и облеченному всей полной власти, впредь до того, как созванное в возможно кратчайший срок на основе всеобщего, прямого, равного и тайного голосования Учредительное собрание своим решением об образе правления выразит волю народа».

На видных местах, с явно пропагандистской целью, в буржуазно-кадетских газетах и журналах Сибири публиковались состав правительства, библиографические данные министров, программные заявления буржуазного Временного правительства. «Сибирская жизнь» поместила даже портреты членов правительства. В передовых редакционных, пространных аналитических статьях местных общественных деятелей с ликованием цитировались и комментировались отдельные фрагменты программы деятельности правительства: «1) Полная и немедленная амнистия по всем делам политическим и религиоз- ным, в том числе по террористическим покушениям, военным восстаниям и преступлениям и т.д.; 2) Свобода слова, печати, союзов, собраний и стачек с распространением политических свобод на военнослужащих в пределах, допускаемых по военно-техническим условиям; 3) Отмена всех сословных, вероисповедных и национальных ограничений; 4) Немедленная подготовка к созыву на началах всеобщего, равного, прямого, и тайного голосования Учредительного собрания, которое установит форму правления и конституцию страны; 5) Замена полиции народной милицией с выборным начальством, подчиненным органам местного самоуправления; 6) Выборы в органы местного самоуправления на основе всеобщего, прямого, равного и тайного голосования; 7) Неразоружение и невывод из Петрограда воинских частей, принимавших участие в революционном движении; 8) При сохранении строгой воинской дисциплины в строю и при несении воинской службы устранение для солдат всех ограничений пользования общественными правами, предоставленными всем остальным гражданам». Здесь же председатель совета министров России Г.Е. Львов, министры П.Н. Милюков, Н.В. Некрасов, А.И. Коновалов, А.Ф. Керенский и др. заверили, что Временное правительство «отнюдь не намерено воспользоваться военными обстоятельствами для какого-либо промедления по осуществлению вышеизложенных реформ и мероприятий». Как показала жизнь, заверение это было неискренним. В частности, Временное правительство всячески затягивало выборы в Учредительное собрание.

И всё же основное место в буржуазно-кадетских газетах и буржуазно-демократических журналах Сибири марта 1917 г. отведено освещению вопроса об организации новой власти на местах. Уже в номере 50 «Сибирской жизни» от 4 марта появилось обращение «Граждане Томска», в котором население информировалось о том, что по распоряжению Временного правительства постановлением городской думы 2 марта учрежден комитет общественного порядка и безопасности в составе десяти человек: 5 - от городской думы - Б.М. Ган (председатель комитета и будущий губернский комиссар Временного правительства, присяжный поверенный и «беспартийный социалист»), С.В. Александровский, Н.В. Патрушев, П.В. Соколов и К.Р. Эман и 5 - от «временного комитета народных партий»: эсер, кооператор В.И. Анучин, эсер-областник, секретарь комитета Е.В. Захаров, меньшевик В.П. Денисов и два известных большевика: А.В. Данилов (Шотман) и А.Ф. Иванов. Здесь же содержался призыв «к сохранению общественного спокойствия и безусловному подчинению распоряжениям Временного правительства», а также предлагалось «о каждом собрании ставить в известность комитет». На первой же странице газеты обосновывается и легитимность новой местной власти: томский губернатор В.Н. Дудинский в специальном «Объявлении» извещал граждан об образовании комитета общественного порядка и безопасности и предлагал исполнять все распоряжения комитета.

На третьей странице этого номера «Сибирской жизни» жирным шрифтом выделен призыв «Граж- 
дане! Содействуйте новому правительству! Организуйтесь! Подчиняйтесь местному исполнительному комитету!». В заметке «Отклики в Томске» сообщается, что правление «Сибирского товарищества печатного дела и редакция газеты «Сибирская жизнь» послали приветственные телеграммы председателю IV Государственной думы М.В. Родзянко, председателю совета министров князю Г.Е. Львову и министру путей сообщения, депутату IV Государственной думы от Томской губернии, бывшему томскому профессору Н.В. Некрасову. Далее описывается процесс формирования городской думой комитета общественного порядка и безопасности. Ещё ниже располагаются заметки «Томский гарнизон признал новое правительство» и «Освобождение политических заключенных». В информации «Настроение» отмечается, что редакция газеты буквально осаждается - ждут новостей из столицы. 2 марта 1917 г. было отпечатано 8 тысяч экземпляров телеграмм в трёх выпусках. Один экземпляр телеграммы стоимостью три копейки вечером продавался в центре города по 20-30 копеек, в отдельных случаях - по 1-1,5 рубля. Тут же констатируется, что обычный тираж «Сибирской жизни» с 1415 тыс. экземпляров поднялся 2 марта до 25 тыс. и к концу дня был исчерпан. В заметке «Постановление томского студенчества» отмечается, что состоялась общегородская сходка студентов, на которой приветствовалось Временное правительство России и говорилось, что настоящие революционные события - это «первый этап к широкой демократизации управления страной».

С первых дней Февральской революции на страницах буржуазно-кадетской «Сибирской жизни» появился выделенный жирным шрифтом лозунг «Да здравствует российская демократическая республика!». Новый редактор «Сибирской жизни» полукадетполуэсер А.В. Адрианов опубликовал в ней статью под характерным названием «Да здравствует республика!». В этой статье буржуазный демократ Адрианов 12 марта 1917 г. выражает уверенность, что сибиряки выскажутся за республику. Такой лозунг полностью соответствовал взглядам столичных конституционных демократов. Лозунг соответствовал и взглядам подавляющего большинства местной кадетской организации. Как сообщала «Сибирская жизнь», 12 марта на организационном собрании томского отдела партии кадетов состоялось голосование по вопросу о власти. За демократическую республику высказались около 1160 человек, за монархию - 8, воздержались 20-30 человек.

В обстановке, когда классовое размежевание в условиях победы Февральской буржуазно-демократической революции по-настоящему только начиналось, когда партия народной свободы была правительственной, её руководство предприняло важный шаг в реализации своей главной цели - довести захватническую войну до победного конца. Уже в декларации Временного правительства от 6 марта 1917 г. прямо говорилось: «Правительство верит, что дух высокого патриотизма в борьбе народа со старою властью, окрылит и доблестных солдат наших на поле брани. Правительство, со своей стороны, приложит все силы к обеспечению нашей армии всем необходимым для того, чтобы довести войну до победного конца». Перепечатав эту декларацию и следуя в фарватере петроградской «Речи», «Сибирская жизнь» из номера в номер пропагандировала тезис: завоеванную русским народом свободу можно и нужно защищать от германского империализма, исходя из того, что после свержения царизма характер войны коренным образом изменился: она из империалистической превратилась в революционную. Поэтому, заявляла «Сибирская жизнь», необходимо единение народа во имя ведения войны.

Очень интересны отклики на Февральскую революцию с мест, помещенные в «Сибирской жизни»самой большой газете региона, имевшей к тому же общесибирское распространение. Редакция ввела на страницах газеты специальную рубрику «По Сибири» (От собственного корреспондента). В ней, в частности, из села Ишим Томского уезда сообщали, что в воскресенье 5 марта на очередном народном чтении в местной школе были прочитаны агентские телеграммы с описанием событий революции и «объяснены простым, понятным языком». Один из организаторов чтения, вероятно учитель, подробно разъяснил «крестьянам о происхождении и значении Государственной думы» и дал характеристики «народным представителям, вставшим во главе народного правительства». Тут же, как бы сейчас сказали «нештатный корреспондент», некто «S» отметил: «Сосредоточенное внимание и радость были заметны на лицах крестьян». Из села Козиха Барнаульского уезда писали: «С чувством большой радости узнали мы о совершившейся перемене правительства и об отречении царя от престола. Радость свою крестьяне выразили тем, что собрались в училище и попросили учителя устроить с учениками манифестацию. Местный священник села Красноярское Мариинского уезда сообщал, что крестьяне волости приняли с энтузиазмом новый строй. В заключение священник Ф. Михайлов отмечал, что манифестация прошла спокойно, избраны временный комитет и милиция.

Из Красноярска, Омска, Тобольска, Тюмени, Канска, Барабинска, со станции Боготол, из села Мазалово Томского уезда и других мест писали в «Сибирскую жизнь» о всеобщем восторге по поводу падения царской власти и о формировании местных органов Временного правительства [4. С. 2-3].

Мы подробно остановились на этих корреспонденциях потому, что они были типичными для всей буржуазно-кадетской печати Сибири тех дней. На страницах «Иркутской жизни», «Омского вестника», «Известий Омского коалиционного комитета», «Алтая» (Бийск) и других газет в изобилии присутствуют подобные материалы. В них также освещаются вопросы о власти, войне и мире и т.д. Так, в передовой статье крупнейшей восточно-сибирской газеты, буржуазно-кадетской «Иркутской жизни», её редактор Н.М. Доброхотов писал 13 марта 1917 г.: «Отложим пока вопросы второстепенные, мелочные. Пусть не мешают они нашей работе. Доверимся всецело правительству, из народных избранников вышедшему, нами признанному, доверимся и властям, этим правитель- 
ством руководимым, ему послушным. Рука об руку с этим правительством доведем до победного конца войну не завоевательную, а освободительную. Граждане! Все без различия положений, занятий, верований, убеждений, все: бедные и богатые, рабочие и хозяева, солдаты и офицеры, служащие, чиновники, республиканцы и конституционалисты, все объединимся в одной мысли: всё для победы, без победы не будет свободы».

В этой газете иркутские кадеты, областники первыми в Сибири поставили вопрос о региональном самоопределении, о сибирской областной думе.

Так же трактовали в марте 1917 г. основные вопросы революции - о власти, войне и мире и другие мелкобуржуазные (социалистические) партии. Кроме того, меньшевики и эсеры сохраняли надежду на демократию. Если меньшевики, оглядываясь на лидеров II Интернационала, считали, что буржуазная революция в России будет развиваться по классической, имеющей всеобщий характер схеме, то социалистыреволюционеры исповедовали идею «особого пути» России к социализму. Лидеры партии считали, что развитие крестьянской кооперации после перехода всей земли в общенародное достояние приведет к созданию саморазвивающихся очагов социализма в экономике. Но после Февральской революции эсеры молча признали меньшевистские аргументы в пользу передачи власти в руки буржуазии. В основе такой оценки революции лежала идея возможности и необходимости примирения классовых противоречий, устранения классовой борьбы. Предстоящий созыв Учредительного собрания и его решения по аграрному вопросу социалисты-революционеры рассматривали как дальнейшее мирное развитие социальной революции в интересах всего народа.

И меньшевики, и эсеры выступили против немедленных практических шагов к социализму, за парламентскую республику, за реформы для рабочих и крестьян, за двоевластие в форме контроля советов над буржуазной властью. Соглашательство правосоциалистических партий эсеров и меньшевиков проявилось и в лозунгах «революционного оборончества», в готовности терпеть оттягивание созыва Учредительного собрания, в призывах к крестьянам воздержаться от стихийных захватов земли. Тактика меньшевиков и эсеров отражала, в том числе и в Сибири, колебания средних слоёв населения, поиск «третьего пути» в революции.

И меньшевики, и эсеры Сибири, как видно из периодики, при всём том, что в их среде были сильны интернационалистические элементы, во время Февральской революции в основном придерживались тактики петроградских эсеров и меньшевиков. Редакторы и авторы материалов и местных печатных изданий излагали идеи, пропагандировавшиеся со столичных газет «Дела народа», «Воли народа», «Рабочей газеты» и др.

Из 72 газет, которые издавались в Сибири в марте 1917 г., 28 были смешанными - эсеро-меньшевистскими, 11 - эсеровскими и 2 - меньшевистскими. Всего, таким образом, в марте 1917 г. социалистыреволюционеры и меньшевики Зауралья контролировали 41 газету, на все другие политические партии и движения приходилась 31 газета - менее 43\% (из них, заметим, 20 - буржуазно-кадетских). А если вспомнить, что эти же эсеры и меньшевики издавали 21 из 31 журнала, выходившего в регионе в первый революционный месяц, то можно отметить явное преобладание правосоциалистических средств массовой информации в Сибири после Февральской революции [5. С. 88-93]. К эсеро-меньшевистским изданиям можно отнести и местные официальные органы Временного правительства - губернские ведомости, выходившие в Томске, Иркутске, Красноярске и Тобольске [6. С. 31-48].

Эти данные представляются нам закономерными, поскольку на 10-11 млн человек населения региона в это время приходилось 8-9 млн крестьян [7. С. 460]. Поэтому агитационно-пропагандистские усилия основных умеренно-социалистических партий - эсеров и меньшевиков - были преимущественно ориентированы на крестьянство и средние слои населения города.

Как и буржуазно-кадетские газеты Сибири, газеты эсеров и меньшевиков касались в основном проблем власти, войны и мира. Крестьянский, рабочий и особенно национальный вопросы после Февраля только начали разрабатываться. То же можно сказать и о соответствующих журналах.

С первых дней Февральской революции эсероменьшевистские газеты и журналы до предела заполнены сообщениями, информациями, письмами с мест о восторгах населения России и Сибири по поводу падения ненавистной всем царской власти и формирования «подлинного народного» Временного правительства и местных органов власти. Тон тут задавала крупнейшая эсеровская газета региона - «Сибирь» (Иркутск). Уже 3 марта 1917 г. её страницы были буквально переполнены агентскими телеграммами, сообщениями из Петрограда о свержении бывшего царя Николая Романова, о составе Временного правительства, его первых практических шагах и планах. В передовой статье газеты её редактор, известный писатель и эсер И.Г. Гольдберг, анализируя причины и следствия начавшейся революции, отмечал, что затянувшаяся мировая война поставила перед Россией ряд грозных и тяжелых задач, но старое правительство оказалось не на высоте. Поэтому под председательством М.В. Родзянко (тут И.Г. Гольдберг допустил ошибку) сформировано Временное правительство, пользующееся доверием народа. В Петрограде сформирован и Совет рабочих депутатов. В русской жизни, отмечал редактор газеты «Сибирь», происходит «крупный перелом». В отличие от других авторов, впадавших в эйфорию первых дней революции, И.Г. Гольдберг уже 3 марта 1917 г. пишет, что нужна тяжелая и трудная работа по преодолению разрухи в стране, а потому нужно идти навстречу требованиям демократии.

В последующих номерах газеты за 4-5, 7-10 марта и т.д. уточняются, расшифровываются, подробно комментируются революционные события в Петрограде, Москве, других городах Европейской России, в городах и селах Сибири. В частности, некто «Р» в пространной статье «К переживаемому моменту» отмечал: «И поскольку новая власть смело борется за 
ликвидацию старого режима и честно идет по пути политического раскрепощения страны - все элементы демократии обязаны поддерживать её всемерно, избегая губительного дробления сил. Ясность и отчётливость политических группировок - первое условие плодотворной совместной работы. И представители цензовой общественности должны ясно осознавать те границы, в пределах которых они могут встретить нашу поддержку» [8. С. 1].

Как видим, и здесь проповедуется идея поддержки, хотя и с оговорками, буржуазного Временного правительства. В статье «Очередная задача», подписанной «Л.П.», эта идея также присутствует, кроме того, разъясняется, что демократия и население Сибири должны настаивать на скорейшем созыве Учредительного собрания и его выборах на основе всеобеего, равного, прямого и тайного голосования, так как только будущее Учредительное собрание вправе образовать постоянную государственную власть и принять стабильную конституцию» [9. С. 2].

Аналогичные статьи мелкобуржуазный читатель мог без труда найти и в других эсеро-меньшевистских газетах и журналах Сибири.

В традиционно эсеро-меньшевистском духе «революционного оборончества» освещались на страницах этих газет и журналов вопросы войны и мира. Дальнейшее ведение войны оправдывалось здесь интересами защиты революции. Чтобы придать большой вес своим словам и убедить массового сибирского читателя, эсеровские и меньшевистские теоретики И.Г. Гольдберг, Е.Е. Колосов, П.Я. Дербер, Н.А. Тетерин, Д.И. Розенберг и другие широко пользовались для подкрепления своего авторитета ссылками на знаменитое обращение Петроградского Совета рабочих и солдатских депутатов «К народам всего мира» от 14 марта 1917 г., в котором, в частности, говорилось: «Мы будем стойко защищать нашу собственную свободу от всяких реакционных посягательств как изнутри, так и извне. Русская революция не отступит перед штыками завоевателей и не позволит раздавить себя внешней военной силой» [10. С. 1]. Но эсероменьшевистские авторы акцентировали своё внимание не на этой фразе, а совсем на другие места «Обращения». Оно было так «революционно» написано и в нём так проклиналась чудовищная война, что крестьяне и представители средних городских слоёв Сибири, в большинстве неграмотные и полуграмотные, были почти не в состоянии разобраться в сути этого опубликованного почти во всех эсеро-меньшевистских газетах и журналах обращения, тем более что в нем говорилось и о заключении мира без аннексий и контрибуций, а народы мира призывались начать борьбу с захватническими стремлениями правительств всех стран.

Также почти во всех эсеровских, меньшевистских, эсеро-меньшевистских газетах и журналах Сибири публиковалась, комментировалась и пропагандировалась принятая под давлением Петроградского Совета «Декларация Временного правительства о задачах войны». В «Декларации» говорилось «о защите завоеваний революции», об утверждении «прочного мира на основе самоопределения народов», отрицались захватнические цели войны, подчеркивалась верность союзникам.

Примечательно, что позиции сибирских эсеров и меньшевиков в периодике (оставляя в стороне интернационалистов из обеих партий) по вопросу о войне и мире удивительно схожи. Чтобы убедиться в этом, достаточно проанализировать оригинальные статьи на эту тему эсеров И.Г. Гольдберга, А.Р. Гоца и другие в «Сибири» (Иркутск), Е.Е. Колосова в «Нашем голосе» (Красноярск), меньшевика Н.А. Рожкова, известного русского историка, - в «Голосе Сибири» (Новониколаевск) и других, агентские телеграммы, перепечатки статей из других газет, перепечатки материалов разнообразных съездов, конференций, совещаний, собраний в газетах «Ермак» (Тюмень), «Известия Курганского Совета рабочих и солдатских депутатов», «Известия Томской губернии», «Енисейский край» (Красноярск), «Известия комитета общественных организаций гор. Иркутска», «Известия Забайкальского областного комитета общественной безопасности» и др.

На страницах этих газет, журналов «Сельскохозяйственная жизнь» (Омск), «Каинский сельскохозяйственный вестник», «Алтайский крестьянин» (Барнаул) и других они убеждали крестьян и средние слои города, что война из империалистической превратилась в необходимое для России «общенародное дело» и что «революционная оборона» отечества предполагает победу над национальным врагом России кайзеровской Германией. Активное участие в войне эсеры и меньшевики Сибири считали залогом успешного развития России в будущем.

Как сговорившись, эсеро-меньшевистские идеологи связывали вопрос о войне и мире с вопросом о созыве Учредительного собрания. Предельно ясно эту точку зрения выразил уже упоминавшийся «Р.» (под этим псевдонимом, по нашему мнению, скрывался известный эсер А.Р. Гоц) в статье «К переживаемому моменту». Он заявил: «Задачей, лежащей сейчас перед страной, является разрешение вопроса о войне и мире... Но как бы та или иная политическая группа не относилась к этому вопросу, одно для нас непреложно: лишь Учредительное собрание, свободно и полно выражающее подлинную волю народа, вправе решить его» [8 C. 2]. Не менее известный меньшевик Н.А. Рожков, вторя ему в новониколаевском «Голосе Сибири», предлагал тогда и нечто почти фантастическое: «Пусть же Учредительное собрание через голову Вильгельма обратится к германскому народу и предложит ему немедленный мир, но мир вот на каких условиях: все народы Европы сливаются в одно большое свободное государство, назовем его Соединенными Штатами Европы» [11. С. 2].

Причём чтобы обосновать правильность своей точки зрения, умеренно социалистические агитаторы и пропагандисты не брезговали и такими шаблонными приемами газетчиков, как ссылка на авторитет. Так, поскольку для многих рабочих и солдат Сибири авторитет большевиков и их газеты «Правда» был довольно высок, то редактор меньшевистской газеты «Утро Сибири» (Томск) В.Е. Воложанин воспользовался некоторыми мартовскими колебаниями ЦК РСДРП (б) и его печатного органа в вопросах о власти и войны и ми- 
ра. В пространной статье В.Е. Воложанин, в частности, писал: “"Правда" изменила свое отношение к войне и теперь заявляет: "Не дезорганизация революционной или революционизирующейся армии, не бессодержательное “Долой войну!”, наш лозунг - давление на Временное правительство с целью заставить его открыто перед всей мировой демократией немедленно выступить с попыткой склонить все воюющие стороны к немедленному открытию переговоров о способах прекращения мировой войны. А до тех пор каждый остается на своем боевом посту"» [12. С. 2].

Отсутствие серьёзных разногласий между социалистами-революционерами, меньшевиками и частью большевиков Сибири в вопросах о власти, войне и мире вылилось в попытки объединить всех социалистов в одной организации. О необходимости этого писалось в «Сибири», «Нашем голосе» и других газетах. В наиболее концентрированном виде такая точка зрения выражена известным эсером Е.Е. Колосовым в статье «Новые течения среди социалистов»: «Социалистическая федерация представляет собой попытку мобилизовать все силы русского социализма в одно целое, объединить их под одними лозунгами, поставить перед ними одни и те же задачи. Она служит полному и всестороннему торжеству и победе нового порядка и безвозвратному крушению старых форм жизни. Как всякая федерация, она вовсе не основана на отрицании права на самостоятельность за теми единицами, которые входят в ее состав. Напротив, пусть все входящие в нее организации социалистов-революционеров и социал-демократов, как были эсерами и кадетами, так ими и остаются. Отказываться им от своего бытия и партийных программ нет нужды и необходимости... теперь не время для партийных споров и пререканий, которым мы отдали в прежнее время такую богатую дань и которые принесли много вреда нашему революционному движению. Теперь перед нами стоят огромные общереволюционные, даже национальные задачи, на достижение которых и должны быть направлены все наши силы. Всякое разобщение будет преступным перед русским народом, так как там, где восторжествует между нами партийная рознь, там всегда выиграет только одна сила - реакция и контрреволюция» [13. С. 2].

Такие попытки объединения социалистов сразу же после Февральской революции были и в других местах России и Зауралья.

Можно отметить и практические попытки образования таких объединений в Сибири. Так, постановлением Томской городской думы 2 марта 1917 г. был учрежден комитет общественного порядка и безопасности. В него кроме пяти представителей от думы вошли и пять представителей, избранных «временным комитетом народных партий», - два эсера, меньшевик и два большевика - видный деятель партии А.В. Шотман (Данилов) и А.Ф. Иванов [14. С. 1].

Правда, послефевральские блоки социалистов, в том числе и в Томске, были недолговечными, ибо нельзя «запрячь» в одну упряжку лебедя, рака и щуку - партии, отражавшие интересы совершенно разных слоев и классов населения, так же как на практике невозможно было издавать серьезную единую большевистско-меньшевистско-эсеровскую газету.
В Сибири, где большевики и меньшевики «сожительствовали» в единых партийных организациях, выходили социал-демократические газеты, в которых печатались эсдеки всех направлений. В том же «Голосе Сибири» можно было на одной странице найти статьи большевика Ф.П. Серебренникова и меньшевика В.И. Герман-Каменского, в якутском «Социалдемократе» - большевика Е.М. Ярославского и меньшевика В.И. Бика, в «Забайкальском рабочем» большевика-примиренца В.Н. Соколова и меньшевика 3.Р. Рубинштейна и др. Более того, в том же якутском «Социал-демократе» соредактором известного большевика Е.М. Ярославского числился меньшевик Г.О. Охтянский. Статьи представителей разных социал-демократических течений соседствовали и на страницах общедемократических газет. Редакции таких изданий («Известия Красноярского Совета рабочих и солдатских депутатов», «Известия Совета солдатских депутатов Томского гарнизона» и др.) объединялись на принципах требования немедленного провозглашения демократической республики, заключения демократического мира без аннексий и контрибуций, созыва Учредительного собрания. Большинство этих газет к осени 1917 г. превратились в пробольшевистские издания.

Большевистских же газет в марте 1917 г. в Сибири не было. Ближе всех к большевистским газетам в то время стоял орган Красноярского комитета РСДРП «Красноярский рабочий». Красноярские большевики Б.3. Шумяцкий, А.И. Окулов, В.Н. Яковлев и другие фактически руководили местной объединенной партийной организацией, что непосредственно отражалось и на содержании «Красноярского рабочего».

Так, если открыть № 14 «Красноярского рабочего» от 25 марта 1917 г., то можно увидеть, что под лозунгом всех большевиков и социал-демократовинтернационалистов России «Пролетарии всех стран, соединяйтесь!» помещена вполне большевистская передовая статья «Неотложная задача». Автор этой статьи, анализируя события Февральской революции, писал, что старый самодержавный строй держался на крупных землевладельцах, богатых помещиках. И революцию они не хотели делать до самого конца. Петроградские рабочие и солдаты сделали ее без содействия и помощи либералов. Буржуазия и помещики только подчинились этой революции, но сделали они это, скрепя сердце, против своей воли.

«Все время, - отмечал автор статьи, - помещики и буржуазия старались ограничить завоевания революции, втайне они мечтали о возврате к старому. Их, правда, немного, но в их руках большая сила: денежные средства и те земли, которыми они владеют. У раздавленной змеи, у богатых, у Николая Романова и его родственников, нужно вырвать ядовитые зубы. Нужно отобрать все их богатства и в первую очередь землю» [15].

А далее автор рассуждал о необходимости международной революции (вероятно, революции социалистической, поскольку он обращался в первую очередь к рабочим и батракам Западной Европы): «Русская революция поставила себе великие задачи. Если Россия останется одинока в своих революционных стремлениях, революция остановится на пол- 
пути, цели ее не будут достигнуты... Русская революция должна найти себе союзников в Западной Европе. Она должна и там зажечь пламя революционного пожара. А для этого она должна смело вести свое дело до конца. Своим примером русский революционный народ скорее всего увлечет на этот путь своих братьев-рабочих и батраков Западной Европы, а вместе с тем подрежет самые глубокие корни нашей реакции» [15].

Конечно, такие статьи в период Февральской революции были единичны, и они терялись среди мно- гочисленных эсеро-меньшевистских, народно-социалистических, буржуазно-кадетских статей и других разнообразных материалов.

Поэтому, как справедливо отмечает М.В. Шиловский, в первые месяцы революции представители этих умеренно социалистических и буржуазных политических партий, имевшие пока преобладающее влияние на местное население, доминировали и в новых местных органах власти - комитетах общественной безопасности, советах рабочих и солдатских депутатов и др. [16. С. 142-153].

\section{ЛИТЕРАТУРА}

1. Государственный архив Российской Федерации. Ф. 6. Оп. 2. Д. 149.

2. Косых Е.Н., Яковенко А.В. Повременная печать Сибири (вторая половина ХІХ века - февраль 1917 г.). Сводный указатель периодических и продолжающихся изданий. Томск, 2011; Косых Е.Н. Периодическая печать Сибири (март 1917 - май 1918 гг.). Указатель газет и журналов. Томск, 2009.

3. Революция и народ (методические и теоретические аспекты) // Октябрьская революция. Народ: её творец или заложник? М., 1992.

4. Сибирская жизнь. 1917. (Томск) 14-15, 17 марта.

5. Косых Е.Н. Периодическая печать Сибири (март 1917 - май 1918 гг.). Указатель газет и журналов. Томск, 2009.

6. Шевцов В.В. Революция и Гражданская война в освещении губернских ведомостей Сибири // Новый исторический вестник. 2014. № 4 (42).

7. Тюкавкин В.Г. Сибирская деревня накануне Октября. Томск, 1966.

8. Сибирь. 1917. (Иркутск). 4 марта.

9. Сибирь. 1917. (Иркутск). 7 марта.

10. Известия Петроградского Совета рабочих и солдатских депутатов. 1917. (Петроград). 15 марта.

11. Голос Сибири. 1917. (Новониколаевск). 7 марта.

12. Утро Сибири. 1917. (Томск). 25 марта.

13. Наш голос. 1917. (Красноярск). 16 марта.

14. Сибирская жизнь. 1917. (Томск) 4 марта.

15. Красноярский рабочий. 1917 (Красноярск). 25 марта.

16. Шиловский М.В. Формирование основных политических группировок в Сибири после Февральской революции (март - июль 1017 г.) // Проблемы истории и исторического познания. Томск, 2001.

Статья представлена научной редакцией «История» 3 декабря 2016 г.

\section{THE FEBRUARY REVOLUTION OF 1917 AND PERIODICALS OF SIBERIA}

Vestnik Tomskogo gosudarstvennogo universiteta - Tomsk State University Journal, 2017, 416, 99-106.

DOI: $10.17223 / 15617793 / 416 / 15$

Evgenii N. Kosykh, Tomsk State University of Architecture and Building (Tomsk, Russian Federation). E-mail: history@tsuab.ru

Keywords: history; Russia; press; Revolution; ideology; party; struggle.

Russia became the freest country in the world at war. The Provisional Government also proclaimed press freedom among other freedoms. The rapid growth of the number of Siberian periodicals became one of the consequences of press freedom declaration in Russia. The growth for the March - September period was more than triple. The same process in journal products was not observed in Siberia. Also, the swift class and party differentiation of periodicals began during the February Revolution, as Russia represented the country with an antagonistic class society in 1917. Ideological and political antagonism, ideological and political fight of classes, parties, individuals were inevitable in such a society, as the specific condition of social being in a historical era finds reflection in public consciousness. Public consciousness, as we know, represents a set of ideas, views and representations existing in society. As in those concrete historical conditions there were no such electronic mass media as the Internet, radio, television, the periodicals naturally acted as mass media. Among 72 newspapers which were issued in Siberia in March, 1917, 28 were mixed - SR-Menshevist, 11 were SR and 2 were Menshevist. Thus, in total, in March, 1917 the Socialist Revolutionaries and the Mensheviks of Transurals controlled 41 newspapers; 31 newspapers, less than $43 \%$ (20 bourgeois and cadet newspapers among them) was the share of all other political parties and movements. It is possible to note the obvious prevalence of the right socialist mass media in Siberia after the February Revolution. These data seem logical, as 8-9 million out of the total of the 10-11 million people of the region at that time were peasants. Therefore, agitation and propaganda efforts of the main moderate socialist parties, the SRs and the Mensheviks, mainly aimed at the peasantry and the middle classes of the city population. As well as the bourgeois and cadet newspapers, newspapers of the SRs and the Mensheviks generally concerned the problems of power, war and peace. Peasant, worker and especially national questions had only begun to develop after February. The same can also be told about the relevant magazines. There were no Bolshevist newspapers and magazines in Siberia in March, 1917. The first Bolshevist newspaper, Sibirskaya pravda (Krasnoyarsk), appeared in the region on 2 April 1917. In the first months of the revolution, representatives of the moderate socialist and bourgeois political parties, who still had prevailing influence on local population, dominated both in new authorities and in the minds and moods of the Siberians.

\section{REFERENCES}

1. State Archive of the Russian Federation. Fund 6. (In Russian).

2. Kosykh, E.N. \& Yakovenko A.V. (2011) Povremennaya pechat' Sibiri (vtoraya polovina XIX veka - fevral' 1917 g.). Svodnyy ukazatel' periodicheskikh i prodolzhayushchikhsya izdaniy [The periodical press of Siberia (the second half of the 19th century - February 1917). Consolidated index of periodicals and continuing editions]. Tomsk: Veter. 
3. Volobuev, P.V. (ed.) (1992) Revolyutsiya i narod (metodicheskie i teoreticheskie aspekty) [Revolution and people (methodological and theoretical aspects)]. In: Oktyabr'skaya revolyutsiya. Narod: ee tvorets ili zalozhnik? [October Revolution. People: its creator or hostage?]. Moscow: Nauka. 4. Sibirskaya zhizn'. (1917). 14-15. 17 March.

5. Kosykh, E.N. (2009) Periodicheskaya pechat' Sibiri (mart 1917 - may 1918 gg.). Ukazatel' gazet i zhurnalov [Periodicals of Siberia (March 1917 - May 1918). Index of newspapers and magazines]. Tomsk: Veter.

6. Shevtsov, V.V. (2014) Revolyutsiya i Grazhdanskaya voyna v osveshchenii gubernskikh vedomostey Sibiri [The Revolution and the Civil War as covered by provincial gazettes of Siberia]. Novyy istoricheskiy vestnik. 4 (42).

7. Tyukavkin, V.G. (1966) Sibirskaya derevnya nakanune Oktyabrya [Siberian village on the eve of the October]. Tomsk Irkutsk: VostochnoSibirskoe knizhnoe izd-vo.

8. Sibir'. (1917). (Irkutsk). 4 March.

9. Sibir'. (1917). 7 March.

10. Izvestiya Petrogradskogo Soveta rabochikh i soldatskikh deputatov. (1917). 15 March.

11. Sibir'. (1917). 4 March.

12. Golos Sibiri. (1917). 7 March.

13. Utro Sibiri. (1917). 25 March.

14. Nash golos. (1917). 16 March.

15. Krasnoyarskij-rabochij. (1917). 25 March.

16. Shilovskiy, M.V. (2001) Formirovanie osnovnykh politicheskikh gruppirovok v Sibiri posle Fevral'skoy revolyutsii (mart - iyul' 1917 g.) [Formation of the main political groupings in Siberia after the February revolution (March-July, 1917)]. In: Zinov'ev, V.P. (ed.) Problemy istorii i istoricheskogo poznaniya [Problems of history and historical knowledge]. Tomsk: Tomsk State University.

Received: 03 December 2016 